Proc. Estonian Acad. Sci. Biol. Ecol., 2003, 52, 3, 236-253

\title{
Benthic communities of four selected habitat types in the sea area of Lahemaa National Park, southern Gulf of Finland
}

\author{
Jonne Kotta $^{\mathrm{a}^{*}}$, Georg Martin ${ }^{\mathrm{a}}$, and Kaire Torn ${ }^{\mathrm{a}, \mathrm{b}}$ \\ ${ }^{a}$ Estonian Marine Institute, University of Tartu, Marja 4D, 10617 Tallinn, Estonia \\ ${ }^{\mathrm{b}}$ Institute of Botany and Ecology, University of Tartu, Lai 40, 51005 Tartu, Estonia
}

Received 9 December 2002, in revised form 10 April 2003

\begin{abstract}
Benthic communities of Lahemaa National Park, Estonia, were mapped in August 2001 in connection with the establishment of Natura 2000 marine areas. Underwater mapping was performed using SCUBA diving. Four bays with a total surface area of $220 \mathrm{~km}^{2}$ were investigated. The spatial distribution of four habitat types of EU habitat Directive Annex I was estimated. The prevailing habitat type was "sandbanks covered with sea water", which made up $26 \%$ of the study area. "Mudflats and sandflats not covered by seawater at low tide" and "reefs" were found in $3 \%$ and $2 \%$ of the cases, respectively. "Higher plant beds" accounted for less than $1 \%$ of the study area. A total of 5 species of Rhodophyta, 7 species of Phaeophyta, 2 species of Chlorophyta, 4 species of Charophyta, 7 species of phanerogams, and 8 species of benthic invertebrates were found in the study area. The differences in geomorphology described the major variability of the benthic communities. Based on the results the studied area is considered as a suitable Natura 2000 site.
\end{abstract}

Key words: habitat types, macrophytobenthos, macrozoobenthos, sediment.

\section{INTRODUCTION}

In the process of Natura 2000 site selection in Estonia 20 marine areas were dedicated to be included in the network, among these the coastal waters of Lahemaa National Park. The main criterion for including a geographical location to Natura 2000 network is the presence of natural habitat types of Community interest. The site selection was problematic due to the lack of relevant information concerning marine areas. Hence, the decision was made to establish a pilot project to fulfil these requirements on a test area of considerable size.

*Corresponding author, jonne@sea.ee 
The aim of the present study was to estimate the areal coverage of natural habitat types in the sea areas of Lahemaa National Park that belong to the category "natural habitat types of Community interest" according to the EU Habitat directive (Council Directive 92/43/EEC). Within each habitat type macrophytobenthic and macrozoobenthic communities were described. We investigated whether the studied habitat types were different in terms of benthic communities. We estimated the nature of relationships between sediment characteristics and biotic factors in the study area.

\section{MATERIAL AND METHODS}

The sea areas of Lahemaa National Park are situated along the southern coast of the Gulf of Finland. Salinity is around 5 PSU in the study area. Mean temperatures range between -0.4 and $25^{\circ} \mathrm{C}$. The study area is situated away from major pollution sources and may be considered to belong among the cleanest in the Gulf of Finland (Pitkänen et al., 1993). Glacier shaped bottom morphology is very diverse resulting in a high variety of natural conditions for benthic plants and animals. In general, the innermost parts of the bays are typified by a wide coastal zone, sandy substrate, and poor macrophyte communities whereas the most exposed parts of the peninsulas have a narrow coastline, diverse bottom substrate, and rich macrophyte communities. As prevailing macroalgal and invertebrate species of the Baltic Sea cannot tolerate salinities below 5 PSU the study area has relatively atypical and instable benthic communities as compared to adjacent sea areas (Kukk, 1978; Yarvekyulg, 1979; Bäck \& Ruuskanen, 2000).

Field work was carried out in four bays of Lahemaa National Park in August 2001. Habitats were mapped in the predefined grid of stations. The total number of sampling points was 145 . The average distance between the stations was 2 nautical miles. The stations were selected to cover areas of different geomorphology and depths.

The sampling was done using diving. During diving the depth and the coverage of different substrate types (stone, boulder, gravel, sand, silt, clay) were recorded. Among biotic variables the coverage of macroalgal and higher plant species were estimated. Additionally, the coverage of sessile macrozoobenthic species such as Mytilus edulis and Balanus improvisus was estimated.

In each site a sample was taken for the taxonomic composition of macrozoobenthos. The sample was sieved through the net of $0.5 \mathrm{~mm}$ mesh size, and the benthic invertebrates were visually determined.

Our mapping data together with the bathymetric and sediment maps were used to assess the habitat type in the areas where sampling was not performed. For that purpose the whole study area was divided into quadrates of $0.2 \times 0.2$ nautical miles. The average coverage of the habitat types is expressed as the percentage of these types within all defined quadrates. 
The definitions for the classified habitat types were obtained from the Estonian adapted version (Paal, 2000) of the Interpretation Manual of European Union Habitats, EUR15/2.

The relationships between the coverage of different sediment types and biotic variables were tested by regression analysis (Sokal \& Rohlf, 1981). Multivariate data analyses were performed by the statistical package PRIMER (Clarke \& Warwick, 1994). The Bray-Curtis similarity measure was used. Ordination was made by nonmetric multidimensional scaling (MDS) (Clarke \& Green, 1988). The statistical differences in invertebrate assemblages between defined groups were obtained by the ANOSIM permutation test (Clarke \& Green, 1988; Clarke, 1993). The contribution of each species to dissimilarities was investigated using the similarities percentages procedure (SIMPER) (Clarke, 1993).

\section{RESULTS AND DISCUSSION}

The following habitat types referred to in the Council Directive 92/43/EEC were found in the study area: " 1110 , sandbanks covered by sea water", " 1120 , higher plant beds" (a substitute for the habitat type "Posidonia beds"), "1140, mudflats and sandflats not covered by sea water at low tide" and "1170, reefs". In the text below the habitat types are referred to as sandbanks, plant beds, mudflats, and reefs, respectively.

Sandbanks were the dominating habitat type in Lahemaa National Park embracing $26 \%$ of the study area (Fig. 1). According to definition this habitat is found from seashore to the lower depth limit of phytobenthos. Altogether 25 plant and 8 invertebrate taxa were found in this habitat type. Fucus vesiculosus and Potamogeton pectinatus occurred at high frequencies whereas Pilayella littoralis, F. vesiculosus, $P$. pectinatus, and Zannichellia palustris had the highest maximum coverages. The habitat type supported diverse and abundant charophyte assemblages. Out of six species of charophytes found in the Estonian coastal sea (Martin, 2001; Torn et al., 2003), four species were observed in that habitat type. Among benthic invertebrates Macoma balthica and Mytilus edulis were the most frequent species (Table 1).

The next dominant habitat type was mudflats. This type was found only in $3 \%$ of the cases (Fig. 2). Although the Baltic Sea has no clear tides (Kullenberg, 1981), the study area is characterized by prominent fluctuations in water level, which are mainly a wind induced phenomenon. Hence, the type is defined here as shallow soft bottom areas occasionally exposed to the air. Altogether 13 plant and 3 invertebrate taxa were found in this habitat type. Chara aspera occurred at the highest frequencies whereas Cladophora glomerata, C. rupestris, and Chara aspera had the highest maximum coverages. Among benthic invertebrates Idotea sp., Hydrobia sp., and Cerastoderma glaucum were the most characteristic of this type (Table 2). 


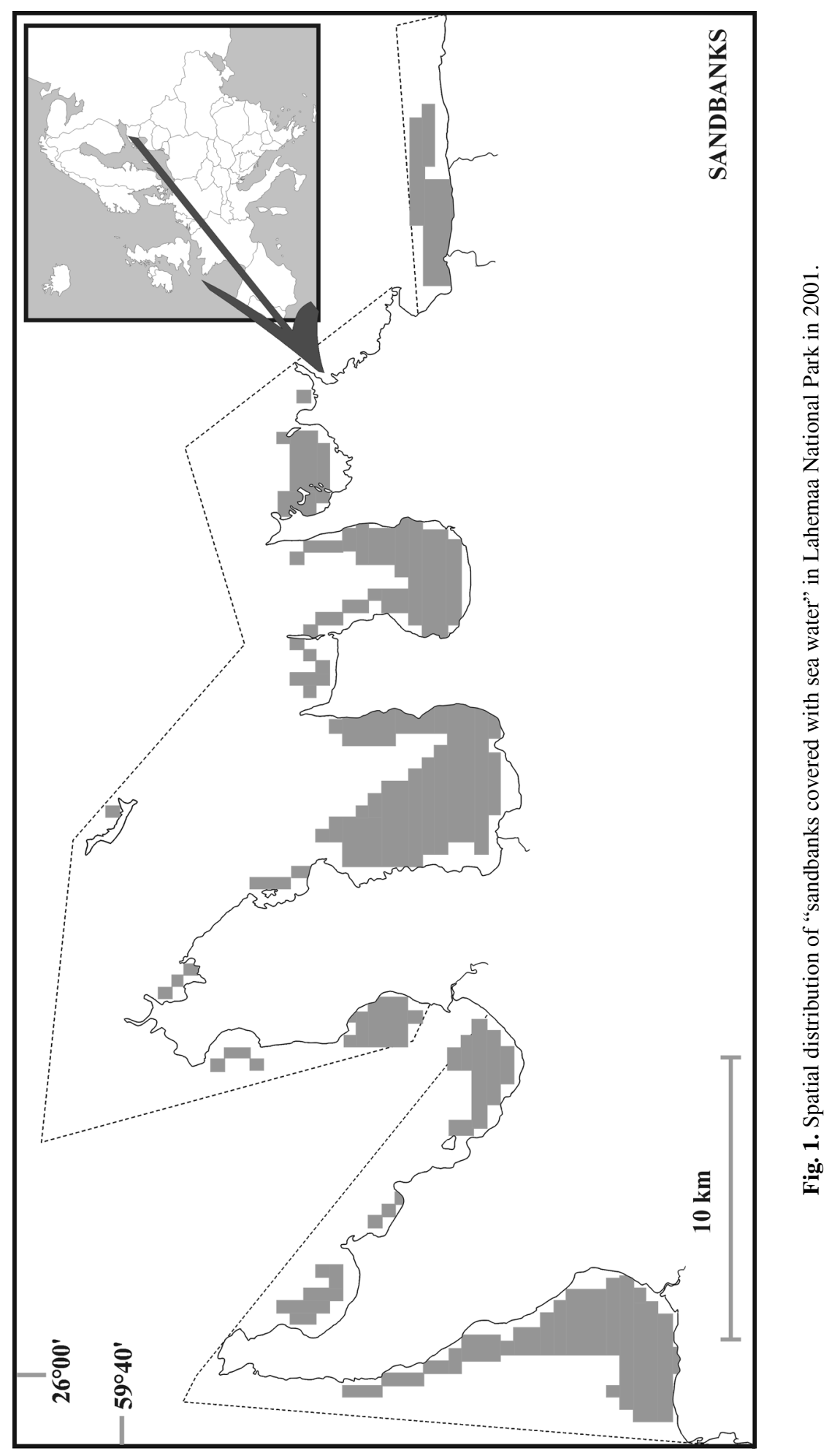


Table 1. Characteristic plant and benthic invertebrate species in "sandbanks covered with sea water" in Lahemaa National Park in 2001

\begin{tabular}{|c|c|c|c|c|}
\hline Species & $\begin{array}{c}\text { Min } \\
\text { depth, } \mathrm{m}\end{array}$ & $\begin{array}{c}\text { Max } \\
\text { depth, } m\end{array}$ & $\begin{array}{l}\text { Coverage, } \\
0-100 \%\end{array}$ & $\begin{array}{l}\text { Occurrence, } \\
\%\end{array}$ \\
\hline \multicolumn{5}{|l|}{ RHODOPHYTA } \\
\hline Ceramium tenuicorne & 1.2 & 12.0 & $0.01-1$ & 10 \\
\hline Furcellaria lumbricalis & 1.2 & 12.0 & $0.01-2$ & 7 \\
\hline Polysiphonia fucoides & 6.0 & 9.2 & $0.01-10$ & 9 \\
\hline Polysiphonia violacea & 5.0 & 9.0 & $0.01-10$ & 3 \\
\hline Rhodomela confervoides & 3.5 & 3.5 & 5 & 1 \\
\hline \multicolumn{5}{|l|}{ РНАЕОРНYТА } \\
\hline $\begin{array}{l}\text { Pilayella littoralis/ } \\
\text { Ectocarpus siliculosus }\end{array}$ & 1.7 & 6.2 & $0.01-100$ & 13 \\
\hline Elachista fucicola & 2.3 & 2.3 & 0.01 & 1 \\
\hline Fucus vesiculosus & 1.3 & 6.5 & $0.01-100$ & 22 \\
\hline Sphacellaria arctica & 6.0 & 10.0 & $0.01-10$ & 6 \\
\hline Stictyosiphon tortilis & 5.0 & 6.5 & 0.01 & 1 \\
\hline \multicolumn{5}{|l|}{ CHLOROPHYTA } \\
\hline Cladophora glomerata & 1.5 & 6.6 & $0.01-50$ & 16 \\
\hline Cladophora rupestris & 4.2 & 5.0 & $3-35$ & 3 \\
\hline \multicolumn{5}{|l|}{ CHAROPHYTA } \\
\hline Tolypella nidifica & 1.2 & 3.8 & 0.01 & 6 \\
\hline Chara aspera & 1.2 & 1.5 & $0.01-50$ & 7 \\
\hline Chara baltica & 1.2 & 1.5 & $0.01-40$ & 4 \\
\hline Chara canescens & 1.3 & 3.2 & $0.01-1$ & 3 \\
\hline \multicolumn{5}{|l|}{ MAGNOLIOPHYTA } \\
\hline Myriphyllum spicatum & 1.0 & 6.2 & $0.01-50$ & 10 \\
\hline Potamogeton pectinatus & 1.0 & 4.8 & $0.01-90$ & 22 \\
\hline Potamogeton perfoliatus & 1.0 & 5.9 & $0.01-70$ & 16 \\
\hline Ranunculus baudotii & 1.3 & 3.8 & $0.01-1$ & 7 \\
\hline Ruppia sp. & 1.2 & 1.3 & $1-5$ & 3 \\
\hline Zannichellia palustris & 1.2 & 6.0 & $0.01-100$ & 14 \\
\hline Zostera marina & 2.3 & 4.8 & $0.01-60$ & 6 \\
\hline \multicolumn{5}{|l|}{ CRUSTACEA } \\
\hline Balanus improvisus & 5.0 & 9.0 & $0.01-30$ & 3 \\
\hline Gammarus sp. & 4.2 & 6.2 & & 4 \\
\hline Idotea $\mathrm{sp}$ & 4.2 & 6.2 & & 3 \\
\hline \multicolumn{5}{|l|}{ GASTROPODA } \\
\hline Hydrobia sp. & 5.5 & 5.5 & & 1 \\
\hline \multicolumn{5}{|l|}{ BIVALVIA } \\
\hline Cerastoderma glaucum & 3.1 & 8.5 & & 4 \\
\hline Macoma balthica & 3.1 & 8.5 & & 9 \\
\hline Mya arenaria & 5.5 & 5.5 & & 1 \\
\hline Mytilus edulis & 3.0 & 9.0 & $0.01-1$ & 6 \\
\hline
\end{tabular}




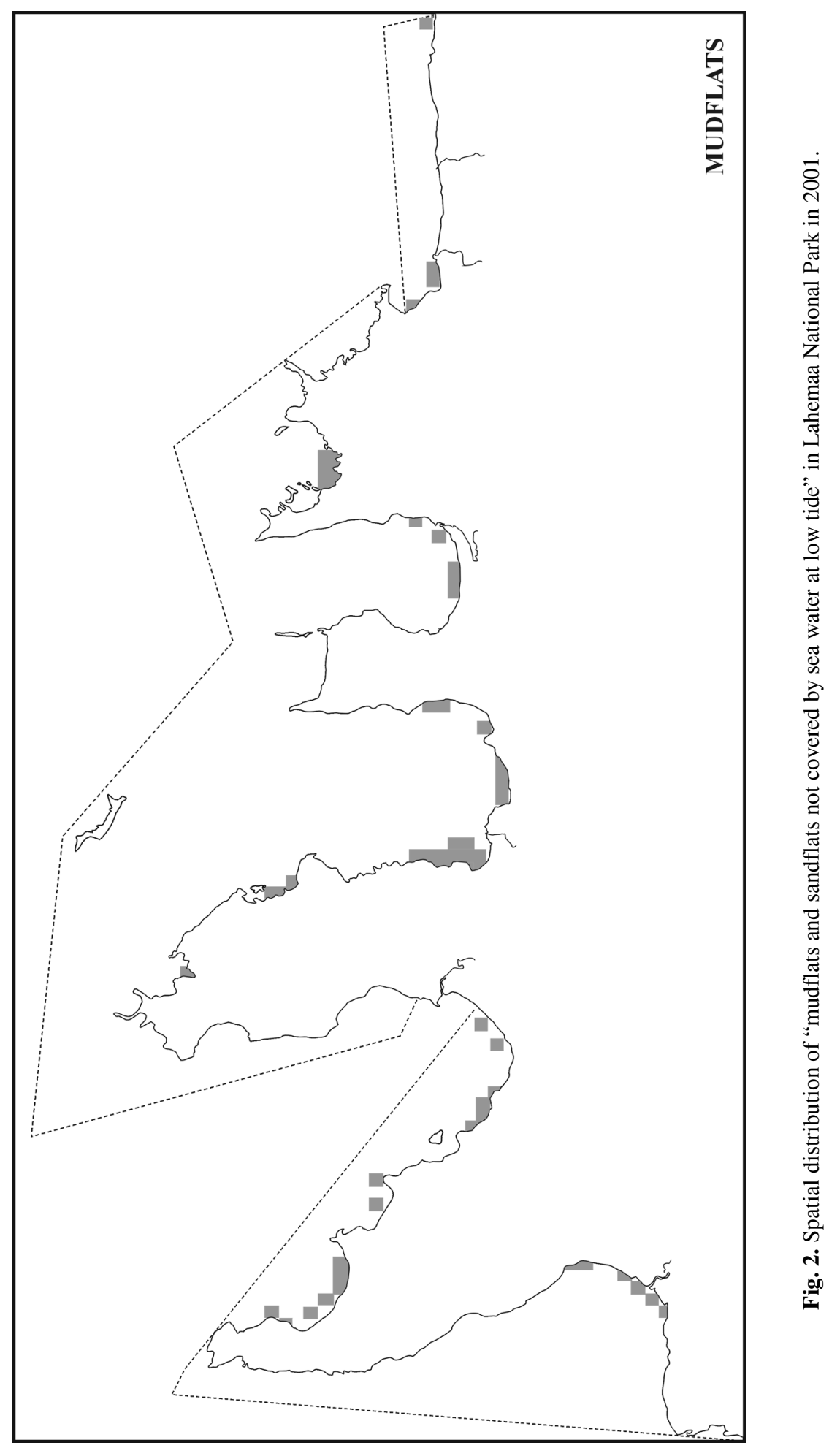


Table 2. Characteristic plant and benthic invertebrate species in "mudflats and sandflats not covered by sea water at low tide" in Lahemaa National Park in 2001

\begin{tabular}{|c|c|c|c|c|}
\hline Species & $\begin{array}{c}\text { Min } \\
\text { depth, m }\end{array}$ & $\begin{array}{c}\text { Max } \\
\text { depth, m }\end{array}$ & $\begin{array}{c}\text { Coverage, } \\
0-100 \%\end{array}$ & $\begin{array}{c}\text { Occurrence, } \\
\%\end{array}$ \\
\hline \multicolumn{5}{|l|}{ PHAEOPHYTA } \\
\hline Chorda filum & 1.0 & 1.0 & 1 & 9 \\
\hline Dictyosiphon foeniculaceus & 1.0 & 1.0 & 1 & 9 \\
\hline Pilayella littoralis/ & 1.0 & 1.0 & 20 & 9 \\
\hline \multicolumn{5}{|l|}{ Ectocarpus siliculosus } \\
\hline Fucus vesiculosus & 0.9 & 1.0 & $1-50$ & 18 \\
\hline \multicolumn{5}{|l|}{ CHLOROPHYTA } \\
\hline Cladophora glomerata & 1.0 & 1.0 & $80-100$ & 27 \\
\hline Cladophora rupestris & 0.8 & 1.0 & $0.01-100$ & 27 \\
\hline \multicolumn{5}{|l|}{ CHAROPHYTA } \\
\hline Chara aspera & 0.2 & 1.0 & $0.01-90$ & 45 \\
\hline Chara baltica & 0.5 & 1.0 & $1-40$ & 18 \\
\hline \multicolumn{5}{|l|}{ MAGNOLIOPHYTA } \\
\hline Myriphyllum spicatum & 0.8 & 0.8 & 5 & 9 \\
\hline Potamogeton pectinatus & 0.7 & 1.0 & $1-10$ & 27 \\
\hline Ranunculus baudotii & 0.8 & 0.8 & 0.01 & 9 \\
\hline Ruppia sp. & 0.7 & 1.0 & $0.01-5$ & 18 \\
\hline Zannichellia palustris & 0.5 & 0.5 & 5 & 18 \\
\hline \multicolumn{5}{|l|}{ CRUSTACEA } \\
\hline Idotea sp. & 0.5 & 1.0 & & 18 \\
\hline \multicolumn{5}{|l|}{ GASTROPODA } \\
\hline Hydrobia sp. & 0.2 & 1.0 & & 45 \\
\hline \multicolumn{5}{|l|}{ BIVALVIA } \\
\hline Cerastoderma glaucum & 0.7 & 1.0 & & 18 \\
\hline
\end{tabular}

Reefs accounted for $2 \%$ of the study area (Fig. 3). A total of 6 plant and 4 invertebrate species were found in this habitat type. The most frequent algal species were $C$. glomerata and $F$. vesiculosus. $C$. glomerata had the highest maximum coverage. The second highest coverage was observed for the filterfeeding crustacean Balanus improvisus (Table 3). High densities of the filterfeeders reflect high pelagic productivity in the area (Yarvekyulg, 1979). As a difference of other habitat types reefs are characterized by high hydrodynamic 


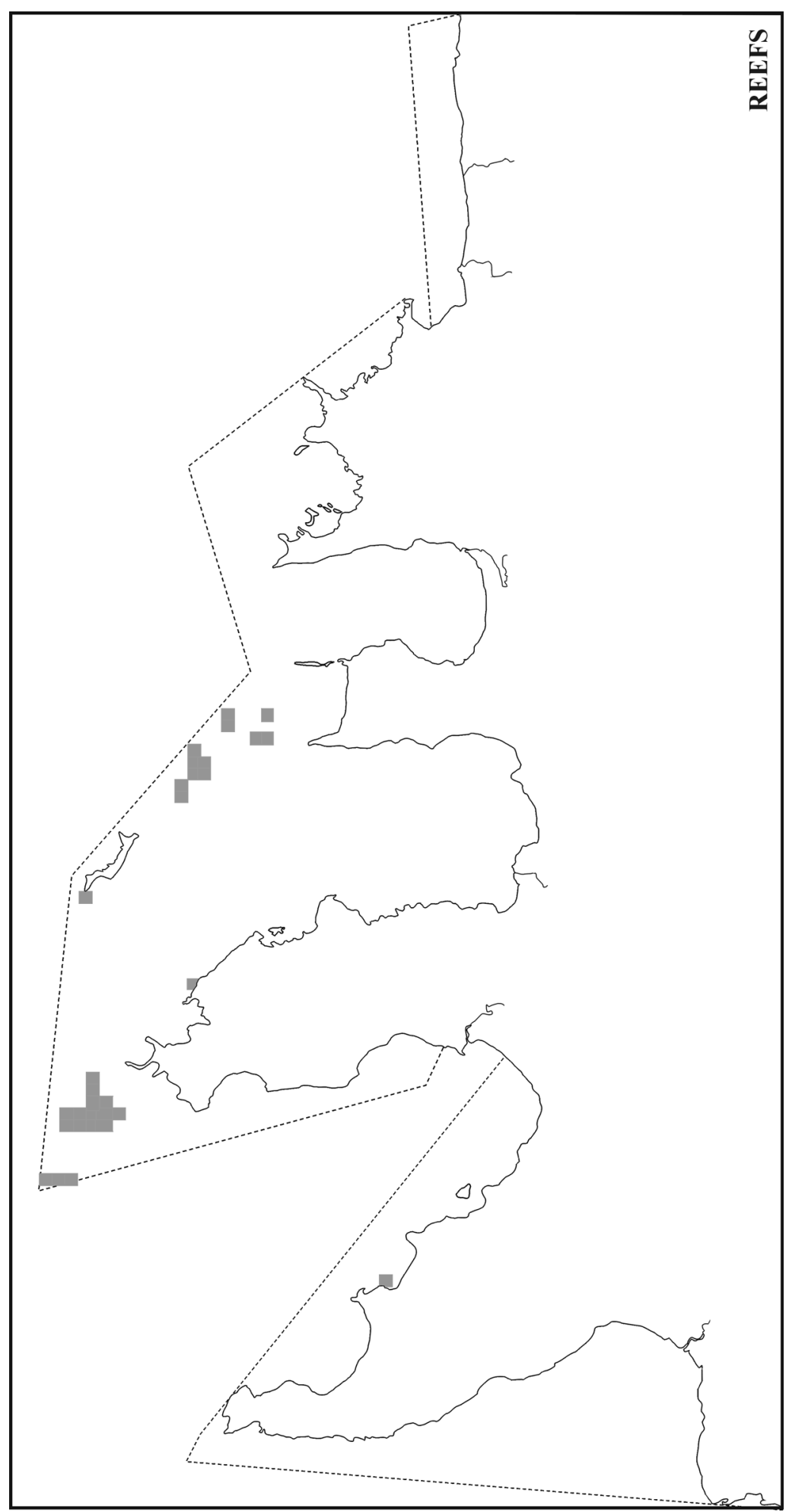

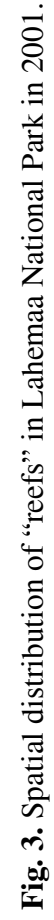


Table 3. Characteristic plant and benthic invertebrate species in "reefs" in Lahemaa National Park in 2001

\begin{tabular}{|c|c|c|c|c|}
\hline Species & $\begin{array}{c}\text { Min } \\
\text { depth, } \mathrm{m}\end{array}$ & $\begin{array}{c}\text { Max } \\
\text { depth, m }\end{array}$ & $\begin{array}{c}\text { Coverage, } \\
0-100 \%\end{array}$ & $\begin{array}{c}\text { Occurrence, } \\
\%\end{array}$ \\
\hline \multicolumn{5}{|l|}{ RHODOPHYTA } \\
\hline Ceramium tenuicorne & 0.4 & 0.6 & $10-30$ & 57 \\
\hline Furcellaria lumbricalis & 5.0 & 5.0 & 50 & 14 \\
\hline \multicolumn{5}{|l|}{ PHAEOPHYTA } \\
\hline Dictyosiphon foeniculaceus & 0.2 & 0.5 & 20 & 29 \\
\hline Pilayella littoralis/ & 6.0 & 6.0 & 5 & 14 \\
\hline \multicolumn{5}{|l|}{ Ectocarpus siliculosus } \\
\hline Fucus vesiculosus & 0.5 & 6.0 & $0.01-50$ & 71 \\
\hline \multicolumn{5}{|l|}{ CHLOROPHYTA } \\
\hline Cladophora glomerata & 0.2 & 6.0 & $5-100$ & 86 \\
\hline \multicolumn{5}{|l|}{ CRUSTACEA } \\
\hline Balanus improvisus & 4.0 & 6.0 & $20-60$ & 57 \\
\hline Gammarus sp. & 0.4 & 6.0 & & 57 \\
\hline Idotea sp. & 5.0 & 5.0 & & 14 \\
\hline \multicolumn{5}{|l|}{ BIVALVIA } \\
\hline Mytilus edulis & 6.0 & 6.0 & 0.01 & 14 \\
\hline
\end{tabular}

activity. It is likely that frequent upwelling of the nutrient rich deep water supports high biological productivity in this habitat type (Kahru et al., 1984; Ojaveer, 1997).

Plant beds accounted for less than $1 \%$ of the study area (Fig. 4). This habitat type was found only within sandbanks. Within this type 11 plant and 1 invertebrate species were found. P. pectinatus had the highest percentage of occurrence whereas $P$. littoralis, $F$. vesiculosus, and Z. palustris had the highest areal coverages. Of benthic invertebrates only M. balthica was found (Table 4).

Comparison of the studied habitat types revealed that sandbanks had a larger species number than other habitat types. The result reflects the highest spatial coverage of the type. When the effect of the areal coverage was removed plant beds became the most diverse habitat type followed by reefs and mudflats. Sandbanks had the lowest species diversity (Fig. 5).

According to MDS analysis the habitat types do not form clearly distinguished groups in terms of the coverage of phytobenthic species (Fig. 6). Plant beds 


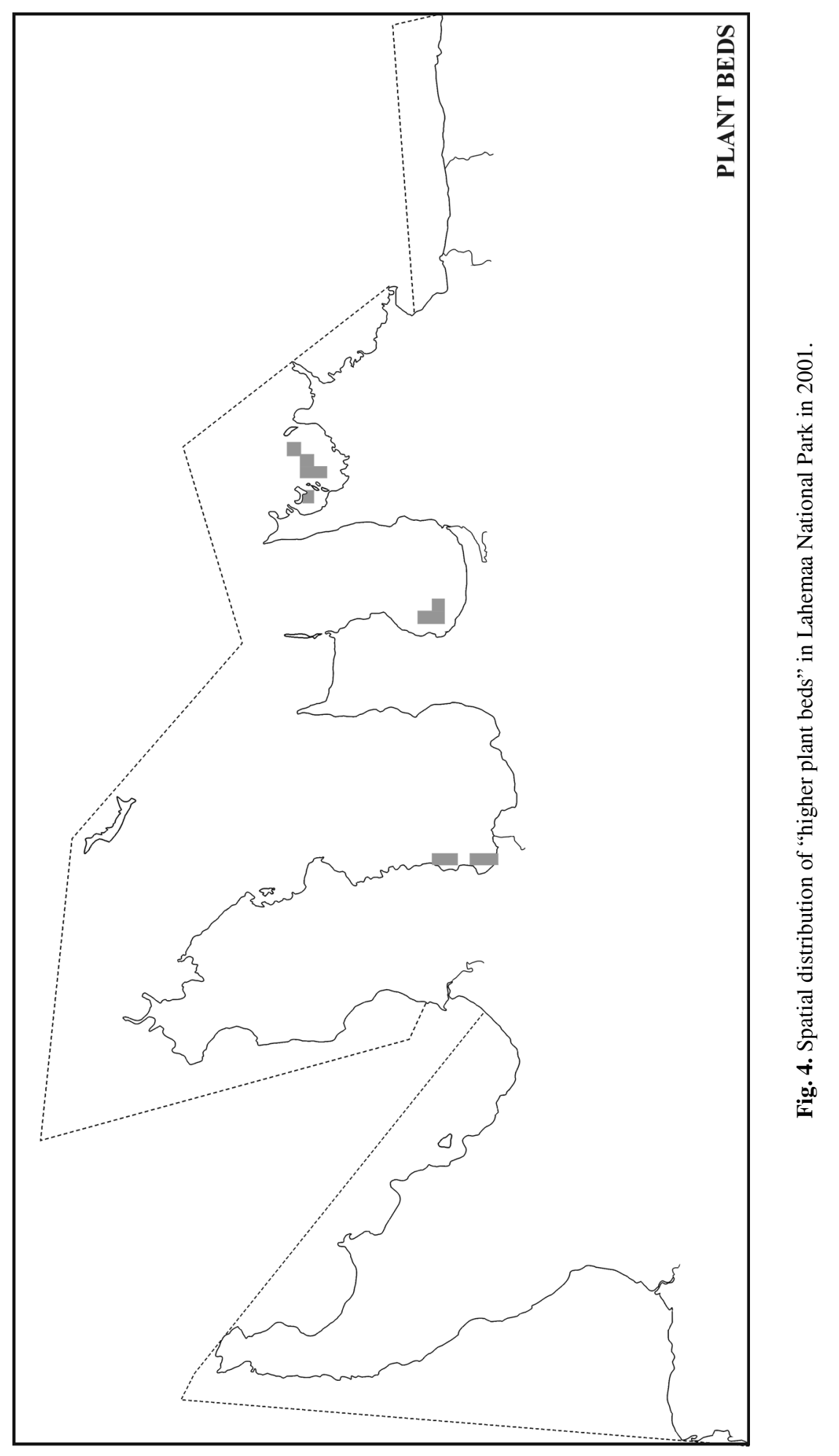


Table 4. Characteristic plant and benthic invertebrate species in "higher plant beds" in Lahemaa National Park in 2001

\begin{tabular}{|c|c|c|c|c|}
\hline Species & $\begin{array}{c}\text { Min } \\
\text { depth, } \mathrm{m}\end{array}$ & $\begin{array}{c}\text { Max } \\
\text { depth, m }\end{array}$ & $\begin{array}{c}\text { Coverage, } \\
0-100 \%\end{array}$ & $\begin{array}{c}\text { Occurrence, } \\
\%\end{array}$ \\
\hline \multicolumn{5}{|l|}{ PHAEOPHYТA } \\
\hline Pilayella littoralis/ & 2.3 & 3.0 & $0.01-100$ & 38 \\
\hline \multicolumn{5}{|l|}{ Ectocarpus siliculosus } \\
\hline Fucus vesiculosus & 1.5 & 3.0 & $0.01-100$ & 38 \\
\hline \multicolumn{5}{|l|}{ CHAROPHYTA } \\
\hline Tolypella nidifica & 1.6 & 1.6 & 0.01 & 13 \\
\hline Chara aspera & 1.5 & 1.5 & 0.01 & 13 \\
\hline Chara baltica & 1.5 & 1.5 & 0.01 & 13 \\
\hline \multicolumn{5}{|l|}{ MAGNOLIOPHYTA } \\
\hline Myriphyllum spicatum & 2.5 & 4.0 & $30-50$ & 25 \\
\hline Potamogeton pectinatus & 1.5 & 4.5 & $0.01-90$ & 100 \\
\hline Potamogeton perfoliatus & 2.3 & 4.5 & $5-70$ & 63 \\
\hline Ranunculus baudotii & 2.3 & 3.8 & $0.01-1$ & 50 \\
\hline Zannichellia palustris & 1.5 & 4.5 & $0.01-100$ & 63 \\
\hline Zostera marina & 2.3 & 4.5 & $5-60$ & 38 \\
\hline \multicolumn{5}{|l|}{ BIVALVIA } \\
\hline Macoma balthica & 1.5 & 4.5 & & 63 \\
\hline
\end{tabular}

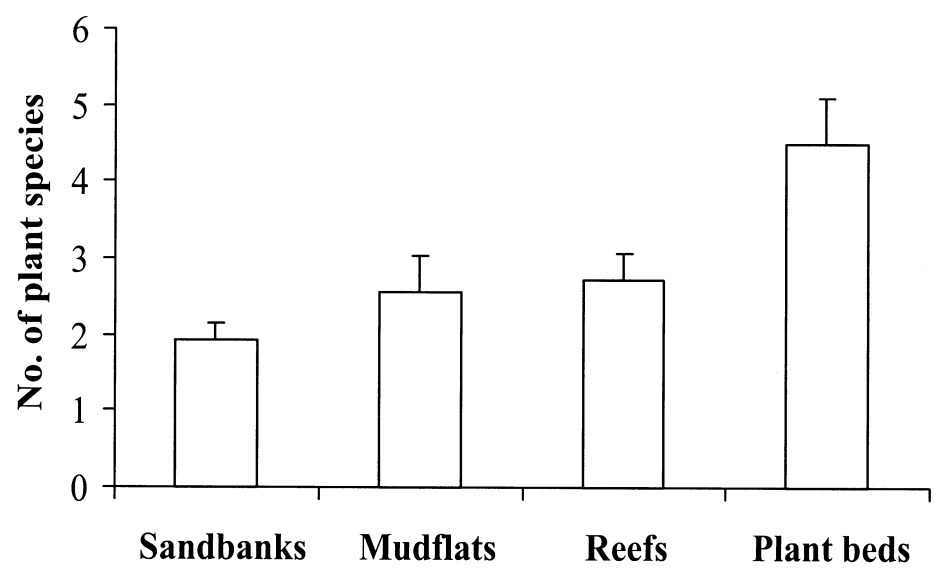

Fig. 5. Average number of plant species at a station within the four studied habitat types. The standard error values are shown. 


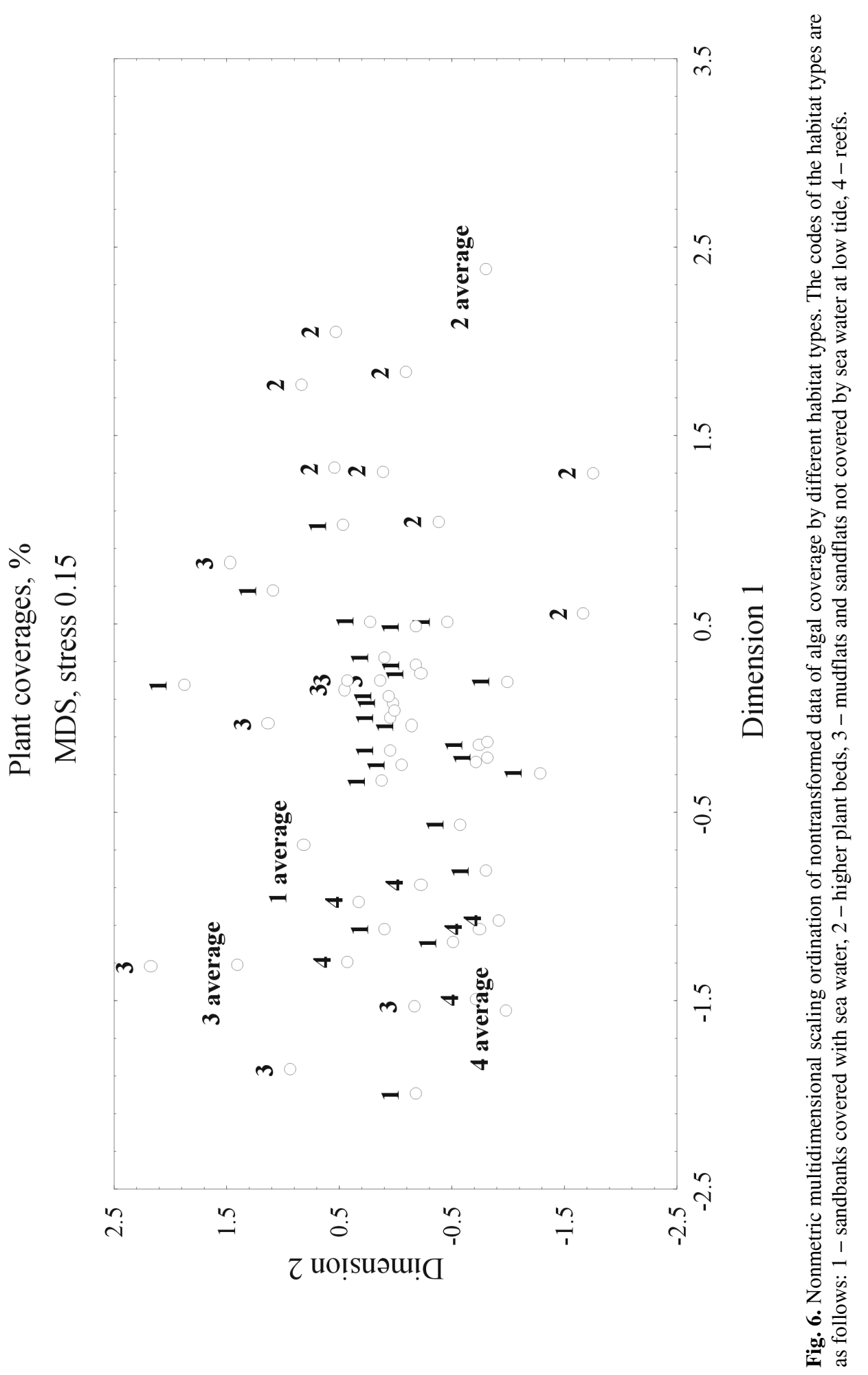


somewhat opposed other habitat types. As the distinction is based on statistical distance not all differences were statistically significant. The transitions between other habitat types were even more gradual.

Reefs had the lowest variability (highest similarity) of benthic communities followed by plant beds and mudflats. The most variable habitat types were recorded within sandbanks. F. vesiculosus, C. glomerata, Potamogeton perfoliatus, P. pectinatus, Tolypella nidifica, and Polysiphonia fucoides described about $90 \%$ of the macroalgal variability in sandbanks. C. glomerata, Z. palustris, and C. aspera were the characteristic species of mudflats; P. pectinatus, P. perfoliatus, $Z$. palustris, and Zostera marina of plant beds; and C. glomerata, F. vesiculosus, and Ceramium tenuicorne of reefs (Table 5).

Table 5. Average coverages together with the share of different plant taxa in the statistical similarities of benthic assemblages within different habitat types

\begin{tabular}{|c|c|c|c|c|}
\hline Habitat type & Species & Average coverage & Percent & Cumulative $\%$ \\
\hline \multirow[t]{7}{*}{ Sandbanks } & Fucus vesiculosus & 9.49 & 41.57 & 41.57 \\
\hline & Cladophora glomerata & 4.55 & 15.61 & 57.18 \\
\hline & Potamogeton perfoliatus & 0.54 & 12.66 & 69.85 \\
\hline & Potamogeton pectinatus & 1.67 & 7.88 & 77.73 \\
\hline & Tolypella nidifica & 0.00 & 5.88 & 83.62 \\
\hline & Polysiphonia fucoides & 0.51 & 4.99 & 88.60 \\
\hline & Average similarity & & & 4.59 \\
\hline \multirow[t]{5}{*}{ Plant beds } & Potamogeton pectinatus & 27.63 & 50.34 & 50.34 \\
\hline & Potamogeton perfoliatus & 19.38 & 27.38 & 77.71 \\
\hline & Zannichellia palustris & 20.13 & 10.18 & 87.89 \\
\hline & Zostera marina & 11.88 & 7.26 & 95.16 \\
\hline & Average similarity & & & 19.80 \\
\hline \multirow[t]{4}{*}{ Mudflats } & Cladophora glomerata & 28.00 & 45.18 & 45.18 \\
\hline & Zannichellia palustris & 1.00 & 20.34 & 65.52 \\
\hline & Chara aspera & 16.55 & 20.13 & 85.65 \\
\hline & Average similarity & & & 7.80 \\
\hline \multirow[t]{4}{*}{ Reefs } & Cladophora glomerata & 35.00 & 47.11 & 47.11 \\
\hline & Fucus vesiculosus & 20.00 & 27.09 & 74.20 \\
\hline & Ceramium tenuicorne & 11.43 & 22.62 & 96.82 \\
\hline & Average similarity & & & 29.93 \\
\hline
\end{tabular}


Comparing the variability of macroalgal communities within and between the studied habitat types we found that only a few differences were statistically significant (ANOSIM, $p<0.05$; Table 6). Surprisingly the difference between sandbanks and reefs was not statistically significant, which probably reflects the high variability of the former type. As expected, plant beds had a significantly higher coverage of higher plants than other habitat types. Charophytes and green algae had the highest coverage in mudflats. Reefs had a moderate coverage of green algae and the highest coverage of $F$. vesiculosus and C. tenuicorne (Table 7).

The variability in the benthic assemblages was significantly related to the nature of the sediment. There was a strong correlation between the coverage of different sediment types, number of plant species, and algal coverage. Both the coverage and the number of algal species increased with the coverage of boulders and decreased with the increase in sandy substrate in the study area (Fig. 7). This is also known from other areas of the Gulf of Finland and the Baltic Sea where substrate type is the most or second most important environmental factor structuring benthic plant and animal communities in the phytobenthic zone (Kautsky, 1988; Kiirikki, 1996; Eriksson et al., 1998; Johansson, 2002).

Earlier studies in the Estonian coastal sea (Orav et al., 2000) revealed that among abiotic variables salinity explains best the variability of benthic assemblages in unvegetated areas and sediment type in vegetated areas. This reflects different phytobenthic species composition on shore bottoms (e.g. reefs) as compared to other sediment types. Spatial differences in salinity in the study area are too small to have any significant effect on benthic assemblages.

Table 6. The results of ANOSIM permutation tests. Significant statistical differences $(p<0.05)$ in the coverage of plant species between different habitat types are marked in bold. The codes of the habitat types are as follows: 1 - sandbanks covered with sea water, 2 - higher plant beds, 3 - mudflats and sandflats not covered by sea water at low tide, 4 - reefs

\begin{tabular}{cc}
\hline Groups used & Significance level, \% \\
\hline 1,2 & 95.1 \\
1,3 & 18.8 \\
1,4 & 98.4 \\
$\mathbf{2 , 3}$ & $\mathbf{0 . 7}$ \\
$\mathbf{2 , 4}$ & $\mathbf{0 . 0}$ \\
$\mathbf{3 , 4}$ & $\mathbf{2 . 1}$
\end{tabular}


Table 7. Average coverages together with the share of different plant taxa in the statistical differences of benthic assemblages between different habitat types. Only the significant differences are presented (see also Table 6)

\section{Mudflats vs plant beds $\quad$ Average dissimilarity $=\mathbf{9 7 . 2 3 \%}$}

\begin{tabular}{l|c|c|c|c}
\hline \multicolumn{1}{c|}{ Species } & $\begin{array}{c}\text { Coverage in } \\
\text { mudflats }\end{array}$ & $\begin{array}{c}\text { Coverage in } \\
\text { plant beds }\end{array}$ & Percent & Cumulative \% \\
\hline Potamogeton pectinatus & 1.60 & 27.63 & 17.51 & 17.51 \\
Potamogeton perfoliatus & 0.00 & 19.38 & 14.23 & 31.75 \\
Zannichellia palustris & 1.00 & 20.13 & 12.23 & 43.97 \\
Cladophora glomerata & 28.00 & 0.00 & 10.68 & 54.65 \\
Fucus vesiculosus & 5.10 & 12.50 & 8.98 & 63.63 \\
Zostera marina & 0.00 & 11.88 & 8.13 & 71.76 \\
Chara aspera & 16.55 & 0.00 & 7.92 & 79.69 \\
Myriophyllum spicatum & 0.50 & 10.00 & 6.34 & 86.02
\end{tabular}

Reefs vs plant beds

Average dissimilarity $=\mathbf{9 7 . 7 8 \%}$

\begin{tabular}{l|c|c|c|c}
\hline \multicolumn{1}{c|}{ Species } & $\begin{array}{c}\text { Coverage in } \\
\text { reefs }\end{array}$ & $\begin{array}{c}\text { Coverage in } \\
\text { plant beds }\end{array}$ & Percent & Cumulative \% \\
\hline Cladophora glomerata & 35.00 & 0.00 & 17.77 & 17.77 \\
Potamogeton pectinatus & 0.00 & 27.63 & 15.17 & 32.93 \\
Fucus vesiculosus & 20.00 & 12.50 & 14.19 & 47.12 \\
Potamogeton perfoliatus & 0.00 & 19.38 & 11.65 & 58.77 \\
Zannichellia palustris & 0.00 & 20.13 & 9.91 & 68.68 \\
Ceramium tenuicorne & 11.43 & 0.00 & 7.09 & 75.77 \\
Zostera marina & 0.00 & 11.88 & 6.82 & 82.59 \\
Myriophyllum spicatum & 0.00 & 10.00 & 5.33 & 87.92
\end{tabular}

Reef vs mudflats $\quad$ Average dissimilarity $=\mathbf{8 8 . 7 1 \%}$

\begin{tabular}{l|c|c|c|c}
\hline \multicolumn{1}{c}{ Species } & $\begin{array}{c}\text { Coverage in } \\
\text { reefs }\end{array}$ & $\begin{array}{c}\text { Coverage in } \\
\text { mudflats }\end{array}$ & Percent & Cumulative \% \\
\hline Cladophora glomerata & 35.00 & 28.00 & 31.92 & 31.92 \\
Fucus vesiculosus & 20.00 & 5.10 & 18.49 & 50.41 \\
Ceramium tenuicorne & 11.43 & 0.00 & 13.20 & 63.62 \\
Chara aspera & 0.00 & 16.55 & 17.90 & 81.52 \\
Furcellaria lumbricalis & 7.14 & 0.00 & 7.06 & 88.58
\end{tabular}



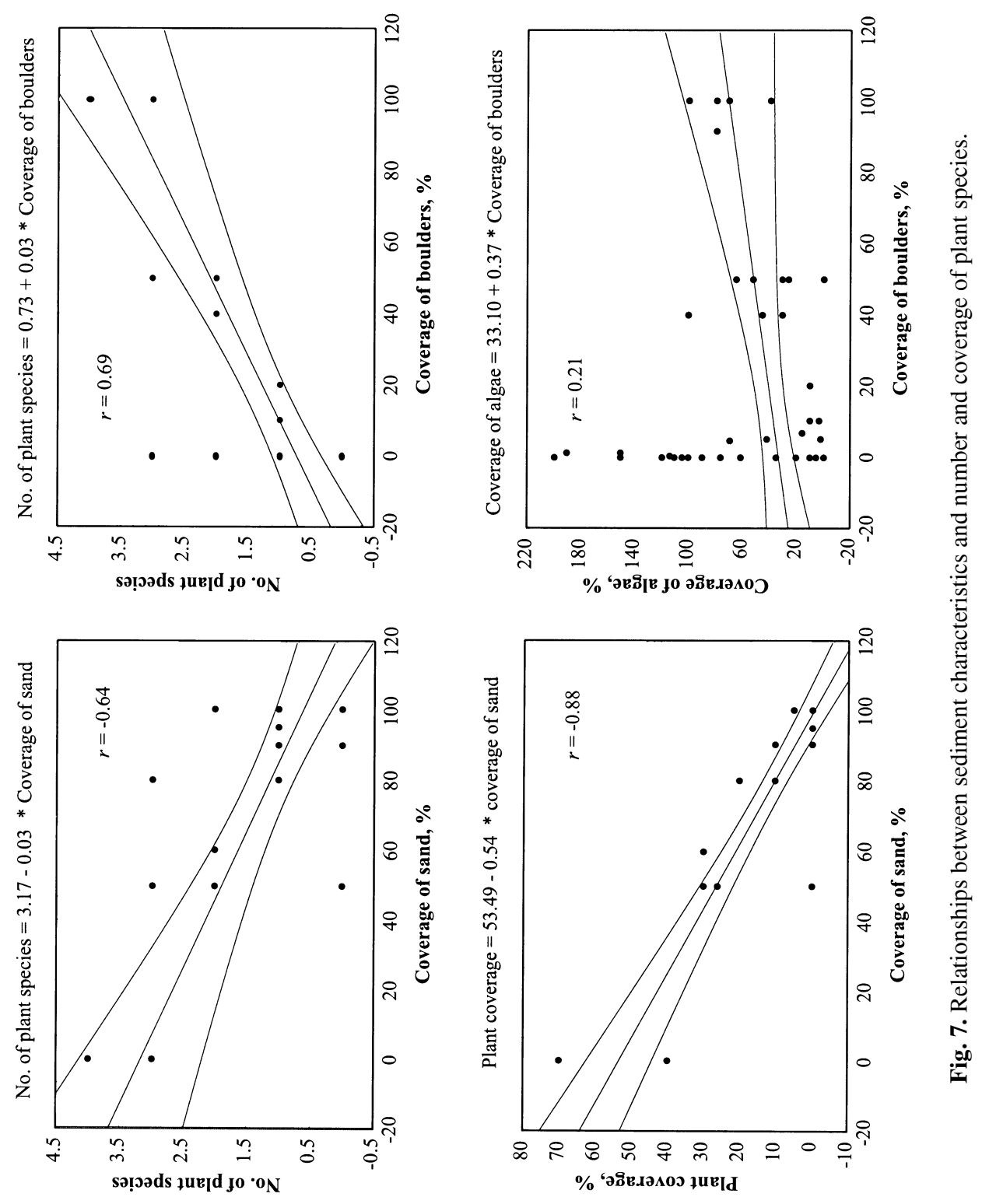


\section{CONCLUSIONS}

Coverage of the natural habitat types that are of interest for Natura 2000 was relatively high in Lahemaa National Park. Within these habitat types benthic diversity and macrophyte density were highly related to the type of substrate, i.e. finer substrate supported less biota than coarser sediment. All habitat types were not distinguished in terms of benthic communities. Hence, an effective protection of a specific type of habitat together with its inhabitants is not possible without protecting adjacent habitats with similar flora and fauna.

\section{ACKNOWLEDGEMENTS}

This study was financed by the Estonian Governmental Program No. 0182578s03, EU 5FP CHARM (EVK3-CT-2001-00065) project, contract No. 2-19-21/249 of the Estonian Ministry of the Environment, and the Estonian Science Foundation grant No. 5103.

\section{REFERENCES}

Bäck, S. \& Ruuskanen, A. 2000. Distribution and maximum growth depth of Fucus vesiculosus along the Gulf of Finland. Mar. Biol., 136, 303-307.

Clarke, K. R. 1993. Non-parametric multivariate analysis of changes in community structure. Aust. J. Ecol., 18, 117-143.

Clarke, K. R. \& Green, R. H. 1988. Statistical design and analysis for a 'biological effects' study. Mar. Ecol. Prog. Ser., 46, 213-226.

Clarke K. R. \& Warwick, R. M. 1994. Changes in Marine Communities: an Approach to Statistical Analysis and Interpretation. Plymouth Marine Laboratory, Plymouth.

Eriksson, B. K., Johansson, G. \& Snoeijs, P. 1998. Long-term changes in the sublittoral zonation of brown algae in the southern Bothnian Sea. Eur. J. Phycol., 33, 241-249.

Johansson, G. 2002. Factors affecting the distribution of rocky-shore macroalgae on the Swedish coast. Morphological, physiological, reproductive and genetic aspects. Acta Univ. Upsal., Compr. Summ. Uppsala Diss. Fac. Sci. Technol., 759.

Kahru, M., Elken, J., Kotta, I., Simm, M. \& Vilbaste, K. 1984. Plankton distributions and processes across a front in the open Baltic Sea. Mar. Ecol. Prog. Ser., 20, 101-111.

Kautsky, H. 1988. Factors Structuring Phytobenthic Communities in the Baltic Sea. Akademitryck, Edsbruk.

Kiirikki, M. 1996. Mechanisms affecting macroalgal zonation in the northern Baltic Sea. Eur. J. Phycol., 31, 225-232.

Kukk, H. 1978. Bottom vegetation in the coastal waters at the southern coast of the Gulf of Finland. Bot. Zh. (Leningr.), 63, 844-852 (in Russian).

Kullenberg, G. 1981. Physical oceanography. In The Baltic Sea (Voipio, A., ed.). Elsevier Oceanogr. Ser., 30, 135-181.

Martin, G. 2001. Distribution of charophytes in Estonian coastal waters. In Charophytes in the Baltic Sea - Threats and Conservation (Yousef, M. A. M. \& Schilbert, H., eds.). Schriftenr. Landschaftspfl. Naturschutz., 72, 31-36. 
Ojaveer, H. 1997. Composition and dynamics of fish stocks in the Gulf of Riga ecosystem. Diss. Biol. Univ. Tartu., 31.

Orav, H., Kotta, J. \& Martin, G. 2000. Factors affecting the distribution of benthic invertebrates in the phytal zone of the north-eastern Baltic Sea. Proc. Estonian Acad. Sci. Biol. Ecol., 49, 253-269.

Paal, J. 2000. Elupaigatüüpide käsiraamat. Eesti Natura 2000. Manuscript. Institute of Botany and Ecology, University of Tartu.

Pitkänen, H., Tamminen, T., Kangas, P., Huttula, T., Kivi, K., Kuosa, H., Sarkkula, J., Eloheimo, K., Kauppila, P. \& Skakalsky, B. 1993. Later summer trophic conditions in the north-east Gulf of Finland and the River Neva Estuary, Baltic Sea. Estuar. Coast. Shelf Sci., 37, 453-474.

Sokal, R. R. \& Rohlf, F. J. 1981. Biometry. The Principles and Practice of Statistics in Biological Research. Second edition. W. H. Freeman, San Francisco.

Torn, K., Martin, G., Kukk, H. \& Trei, T. 2003. Distribution of charophyte species in Estonian coastal water (NE Baltic Sea). Sci. Mar., 67 (in press).

Yarvekyulg, 1979. Bottom Fauna in the Eastern Part of the Baltic Sea. Valgus, Tallinn (in Russian).

\title{
Põhjakooslused neljas Lahemaa rahvuspargi rannikumere elupaigatüübis
}

\author{
Jonne Kotta, Georg Martin ja Kaire Torn
}

Lahemaa rahvuspargi põhjakooslusi kaardistati 2001. aasta augustis seoses Natura 2000 merealade loomisega. Kaardistamine toimus sukeldumise abil. Kokku uuriti nelja lahte üldpindalaga 21965 ha. Hinnati Euroopa Liidu veedirektiivis välja toodud elupaigatüüpide ruumilist levikut. Levinuim elupaigatüüp oli mereveega üleujutatud liivamadalad, mis võttis enda alla $26 \%$ uurimisalast. Mõõnaga paljanduvaid mudaseid ja liivaseid laugmadalikke ning karisid leiti vastavalt 3 ja $2 \%$ juhtudel. Kõrgemate veetaimede koosluseid oli vähem kui $1 \%$ uurimisalast. Taimedest leiti uurimisalal kokku 5 Rhodophyta, 7 Phaeophyta, 2 Chlorophyta, 4 Charophyta ja 7 kõrgemate taimede liiki. Selgrootuid leiti kokku 8 liiki. Koosluste ruumilist muutlikkust kirjeldas kõige paremini põhja geomorfoloogia. Uurimistulemuste põhjal vastab uurimisala Natura 2000 alade kriteeriumitele. 